\title{
Ocena świadomości prozdrowotnej studentów V roku kierunku lekarsko-dentystycznego w kontekście pracy ergonomicznej
}

\author{
Evaluation of pro-healthy awareness among $5^{\text {th }}$ year dental students \\ in the context of ergonomic work
}
Klinika Stomatologii Zachowawczej i Endodoncji, Uniwersytet Medyczny im. Karola Marcinkowskiego w Poznaniu Department of Conservative Dentistry and Endodontics, Poznan University of Medical Sciences
2 Studenckie Koło Naukowe przy Klinice Stomatologii Zachowawczej i Endodoncji, Uniwersytet Medyczny im. Karola Marcinkowskiego w Poznaniu
Students Scientific Association, Department of Conservative Dentistry and Endodontics, Poznan University of Medical Sciences
* autorzy deklarują równy wkład autorski

DOI: http://dx.doi.org/10.20883/df.2020.10

\section{STRESZCZENIE}

Wprowadzenie. Lekarze dentyści są grupą zawodową szczególnie narażoną na wysokie ryzyko schorzeń układu mięśniowo-szkieletowego. Coraz częściej zdarza się, że już na etapie pracy przeddyplomowej studenci stomatologii borykają się z dolegliwościami bólowymi spowodowanymi niewłaściwymi nawykami i nieodpowiednią postawą w trakcie wykonywania procedur klinicznych.

Cel. Ocena świadomości prozdrowotnej studentów V roku kierunku lekarsko-dentystycznego w kontekście pracy ergonomicznej.

Materiał i metody. Badanie ankietowe przeprowadzono w latach 2017-2019 wśród 219 studentów V roku kierunku lekarsko-dentystycznego Uniwersytetu Medycznego im. Karola Marcinkowskiego w Poznaniu. Każdy uczestnik badania wypełnił anonimową ankietę dotycząca pozycji podczas pracy klinicznej, własnych obserwacji oraz wiedzy na temat zachowań prozdrowotnych. Wszystkich ankietowanych podzielono na dwie grupy według płci (157 kobiet i 62 mężczyzn) oraz przeprowadzono porównawczą analizę statystyczną.

Wyniki. Kobiety już na etapie przeddyplomowej pracy klinicznej częściej odczuwają dolegliwości bólowe ze strony układu ruchu związane z wykorzystywaniem, w celu poprawy pola widzenia, bocznego zgięcia tułowia i szyi. Ponadto wykazują znacznie mniejszą aktywność fizyczną niż mężczyźni.

Wnioski. Znajomość teoretycznych zasad pracy ergonomicznej nie gwarantuje właściwej pozycji podczas pracy klinicznej z pacjentem. Oprócz edukacji i treningu ergonomii należy wziąć pod uwagę odpowiedni projekt stanowiska pracy, okresy odpoczynku podczas pracy i regularne ćwiczenia fizyczne. Wyrobienie nawyku ergonomicznej pozycji pracy w trakcie studiów jest kluczowe dla sukcesu w dalszej pracy zawodowej.

Słowa kluczowe: studenci stomatologii, ergonomia pracy, świadomość prozdrowotna.

\section{ABSTRACT}

Introduction. Dentists, as an occupational group, are particularly exposed to the high risk of musculoskeletal disorders. Dental students increasingly suffer from pain caused by improper habits and inappropriate attitudes during clinical procedures, already at the stage of pre-graduate work.

Aim. To evaluate a pro-healthy awareness among 5th year dental students in the context of ergonomic work.

Material and Methods. The survey was conducted between 2017-2019 among 219 dental students of the 5th year at the Poznan University of Medical Sciences. Each participant completed an anonymous questionnaire concerning their position during clinical work, their own observations and knowledge of pro-healthy behaviour. All respondents were divided into two groups according to gender (157 women and 62 men) and a comparative statistical analysis was performed.

Results. Already at the stage of pre-diploma clinical work, women are more likely to experience musculoskeletal pain associated with the use of the lateral bend of the torso and neck to improve their field of vision. Moreover, they show much less physical activity than men.

Conclusions. Knowledge of the theoretical principles of ergonomic work does not guarantee the correct position at clinical work with the patient. In addition to education and training in ergonomics, appropriate workplace design, rest periods at work and regular physical exercise must be taken into account. Developing the habit of an ergonomic working position during the studies is key to the success in the future dental career.

Keywords: dental students, work ergonomics, pro-healthy awareness. 


\section{Wprowadzenie}

Znaczną część pracy zawodowej lekarza dentysty, obok wysiłku umysłowego, stanowi statyczna praca fizyczna. Bardzo często zdarza się, iż dentyści, dążąc do uzyskania jak najlepszej widoczności podczas zabiegów, przyjmują postawę niefizjologiczną i obciążającą kręgosłup. Zaburzenia ze strony układu mięśniowo-szkieletowego są spowodowane najczęściej długotrwałym przebywaniem w tej samej wymuszonej pozycji. Wśród czynników ryzyka wymienia się także powtarzalność ruchów i siłę, z jaką są wykonywane, nieodpowiednie oświetlenie pola zabiegowego, nieprawidłowe ustawienie pacjenta oraz asysty. Zarówno praca w pozycji stojącej, jak i siedzącej powoduje nadmierne obciążenie ciała operatora. Początkowo bóle pojawiają się pod koniec dnia pracy, z czasem nasilają się i trwają dłużej, prowadząc do trwałych zmian zwyrodnieniowych i w konsekwencji do bólu samoistnego [1-3]. Uważa się, że na dolegliwości mięśniowo-szkieletowe, zależne od wykonywanej pracy, może uskarżać się aż około 70\% lekarzy dentystów [4, 5]. Najczęstszymi dolegliwościami, które występują u lekarzy stomatologów są przewlekłe bóle kręgosłupa w odcinku szyjnym i lędźwiowym. Do chorób zawodowych związanych z pracą lekarza dentysty zalicza się: zwyrodnienia kręgosłupa w odcinku szyjnym, piersiowym i lędźwiowym, zespół cieśni nadgarstka, zapalenie nadkłykcia przyśrodkowego i bocznego kości ramiennej, zapalenia okołostawowe barku, uszkodzenie łąkotki oraz martwicę kości nadgarstka. Piśmiennictwo podaje, że nawet studenci kierunku lekarsko-dentystycznego, wykonujący niewielką ilość procedur zawodowych, skarżą się na dolegliwości związane z układem ruchu. Najczęściej dotyczą one bólu karku i kręgosłupa w odcinku lędźwiowym [6, 7]. Jeśli tylko kilka godzin ćwiczeń klinicznych tygodniowo przy fotelu dentystycznym powoduje już ból co będzie później, gdy lekarz będzie zobowiązany pracować czasem do kilkunastu godzin dziennie? Wielu badaczy wskazuje na konieczność wdrożenia bardziej wydajnego treningu zasad ergonomii, nie tylko podczas studiów, ale i w trakcie kształcenia podyplomowego [8-11].

W programie nauczania przeddyplomowego ergonomia znajduje się zwykle na I lub II roku studiów. Studenci uczą się właściwych postaw, niestety bez jednoczasowego wykonywania procedur, co może być przyczyną późniejszych błędów podczas pracy przy pacjencie. Dodatkowo, na zajęciach klinicznych dochodzi jeszcze stres związany $z$ oceną efektu finalnego wykonywanego zabiegu - student za wszelką cenę chce wykonać zadaną procedurę, niejednokrotnie kompletnie zapominając o zasadach ergonomii. Bardzo ważne jest, aby asystenci obecni na ćwiczeniach korygowali wadliwe postawy studentów, pomagali w odpowiednim ustawieniu pacjenta oraz operatora tyle razy, ile jest to konieczne.

Wydaje się również istotne, aby studenci stomatologii nie zapominali o codziennej aktywności fizycznej. Treningi, zwłaszcza siłowe, pomagają w wykształceniu odpowiedniego gorsetu mięśniowo-powięziowego, który w przyszłości będzie chronił przed wystąpieniem urazów przeciążeniowych na skutek długoczasowej pracy klinicznej $[12,13]$.

\section{Cel}

Celem pracy była ocena wiedzy studentów $\mathrm{V}$ roku kierunku lekarsko-dentystycznego na temat ergonomii pracy oraz najczęstszych trudności, z jakimi borykają się podczas wykonywania zabiegów klinicznych u pacjentów podczas zajęć ze stomatologii zachowawczej z endodoncją. W ankiecie pojawiły się także pytania dotyczące preferowanej aktywności fizycznej.

\section{Materiał i metody}

Badanie ankietowe przeprowadzono wśród 219 studentów $\mathrm{V}$ roku kierunku lekarsko-dentystycznego Uniwersytetu Medycznego im. Karola Marcinkowskiego w Poznaniu. Wszyscy uczestnicy badania wypełniali anonimową ankietę dostępną online w latach 2017-2019. Autorski kwestionariusz ankiety został przygotowany na podstawie podobnych narzędzi dostępnych w piśmiennictwie [14] i przetestowany w badaniu pilotażowym na grupie 15 studentów. Ankieta składała się z 17 pytań zamkniętych oraz 12 otwartych, które dotyczyły znajomości zasad ergonomii w pracy lekarza dentysty oraz ich stosowania w praktyce, dolegliwości ze strony układu mięśniowo-szkieletowego związanych z pracą kliniczną, osobistych obserwacji i współpracy z asystentami podczas ćwiczeń oraz preferowanej aktywności fizycznej. Wykonano analizę statystyczną z wykorzystaniem programu Statistica 13.3 (StatSoft, Kraków) - zastosowano test dokładny Fishera dwustronny $z$ istotnością statystyczną ustaloną na poziomie $a=0,05$.

\section{Wyniki}

Porównanie odsetka odpowiedzi twierdzących na pytania zamknięte u kobiet i mężczyzn przedstawiono $w$ tabeli 1. Największą różnicę pomiędzy odpowiedziami kobiet i mężczyzn wykazano przy pytaniu o aktywność fizyczną. Z ankiety wynika, 
iż do regularnych ćwiczeń przyznaje się aż 87,1\% mężczyzn i tylko 65\% kobiet. Badane kobiety istotnie częściej przyznawały się do wykorzystywania bocznego zgięcia tułowia i szyi w celu poprawy pola widzenia (94,3\% vs. $82,3 \%$ ). Niestety, znacznie częściej niż mężczyźni odczuwają również dolegliwości ze strony ruchu podczas pracy klinicznej (65,6\% vs. 41,9\%). Aż 80,9\% kobiet zwraca uwagę na to, aby podczas pracy łokcie były przywiedzio- ne do tułowia. U mężczyzn ten odsetek wynosił 59,7\%. Różnica była istotna statystycznie.

Z kolei wykresy słupkowe zamieszczone na rycinach 1-7 przedstawiają rozkład procentowy najczęstszych odpowiedzi na pytania otwarte dotyczące ergonomii pracy, na które studenci mogli udzielić więcej niż jedną odpowiedź. W obu grupach trudności z pracą w pośrednim polu widzenia stanowiły najczęstszą przyczynę problemów w za-

Tabela 1. Odsetek odpowiedzi twierdzących w poszczególnych grupach studentów (test dokładny Fishera dwustronny - pogrubione różnice istotne statystycznie dla $\mathrm{p}<0,05)$

Table 1. Percentage of affirmative answers in selected student groups (two-sided Fisher's exact test - bold statistically significant differences for $p$-value $<0.05$ )

\begin{tabular}{|l|c|c|c|}
\hline & $\begin{array}{c}\text { kobiety [\%] } \\
\mathrm{n}=157\end{array}$ & $\begin{array}{c}\text { mężczyźni [\%] } \\
\mathrm{n}=62\end{array}$ & $\mathrm{p}$-value \\
\hline Czy znasz zasady pracy ergonomicznej? & 96,8 & 91,9 & 0,151 \\
\hline Czy pracujesz z pacjentem leżącym? & 89,2 & 91,9 & 0,626 \\
\hline Czy dopasowujesz pozycję pacjenta do siebie? & 93,0 & 95,2 & 0,762 \\
\hline Czy uzależniasz pozycję pacjenta od leczonego zęba? & 93,6 & 96,8 & 0,516 \\
\hline Czy podczas wykonywania zabiegu masz proste plecy? & 72,6 & 69,4 & 0,622 \\
\hline Czy w czasie pracy twoje łokcie są przywiedzone do tułowia? & 80,9 & 59,7 & 0,002 \\
\hline Czy podczas pracy twoje uda i podudzia ustawione są pod kątem prostym? & 72,0 & 69,4 & 0,741 \\
\hline Czy w trakcie pracy twoje stopy są płasko położone na podłodze? & 75,2 & 80,6 & 0,479 \\
\hline Czy masz problem z pracą w pośrednim polu widzenia? & 65,0 & 59,7 & 0,534 \\
\hline Czy wykorzystujesz boczne zgięcia tułowia i szyi w celu poprawy pola widzenia? & 94,3 & 82,3 & 0,009 \\
\hline $\begin{array}{l}\text { Czy podczas pracy klinicznej asystent prowadzący zwrócił Ci uwagę na nieprawidłową } \\
\text { pozycję ciała? }\end{array}$ & 64,3 & 62,9 & 0,877 \\
\hline Czy dostrzegasz wadliwą pozycję podczas pracy u swoich kolegów/koleżanek? & 93,6 & 96,8 & 0,516 \\
\hline Czy na praktykach wakacyjnych widziałeś lekarzy pracujących nieergonomicznie? & 77,1 & 80,6 & 0,717 \\
\hline Czy podczas pracy klinicznej odczuwasz dolegliwości bólowe ze strony układu ruchu? & 65,6 & 41,9 & 0,002 \\
\hline Czy po pracy klinicznej odczuwasz dolegliwości bólowe ze strony układu ruchu? & 69,4 & 54,8 & 0,058 \\
\hline $\begin{array}{l}\text { Czy jesteś świadomy tego, że regularna aktywność fizyczna pomaga w utrzymaniu odpo- } \\
\text { wiedniego napięcia mięśniowego? }\end{array}$ & 98,7 & 100,0 & 1,000 \\
\hline Czy jesteś aktywny fizycznie? & 65,0 & 87,1 & $<0,001$ \\
\hline
\end{tabular}

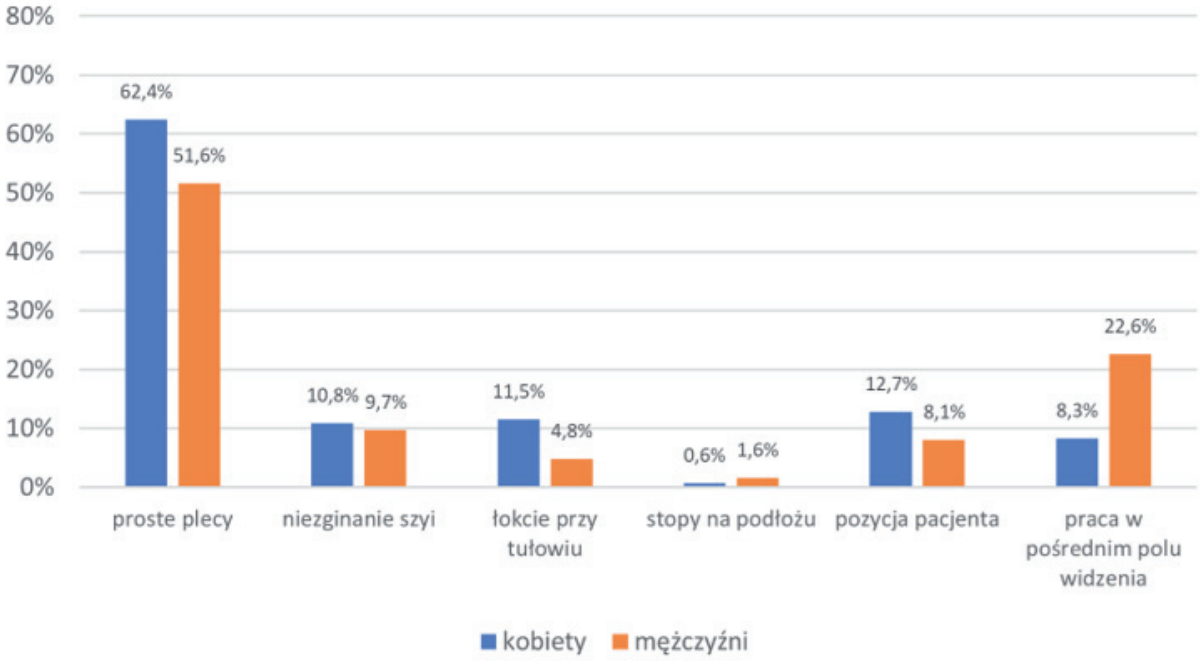

Rycina 1. Z zachowaniem której zasady ergonomii masz największy problem?

Figure 1. Which ergonomic principle do you have the most trouble with? 


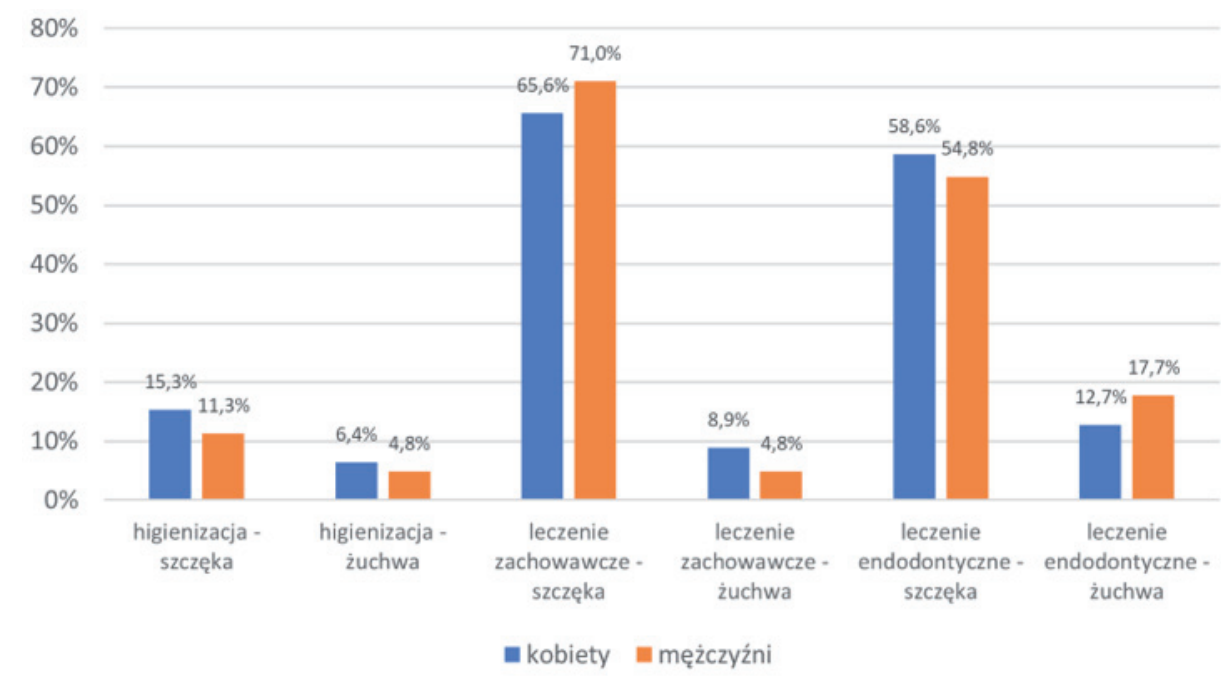

Rycina 2. Podczas których zabiegów masz największe problemy z zachowaniem pozycji ergonomicznej?

Figure 2. During which procedures do you have the most trouble maintaining the ergonomic position?

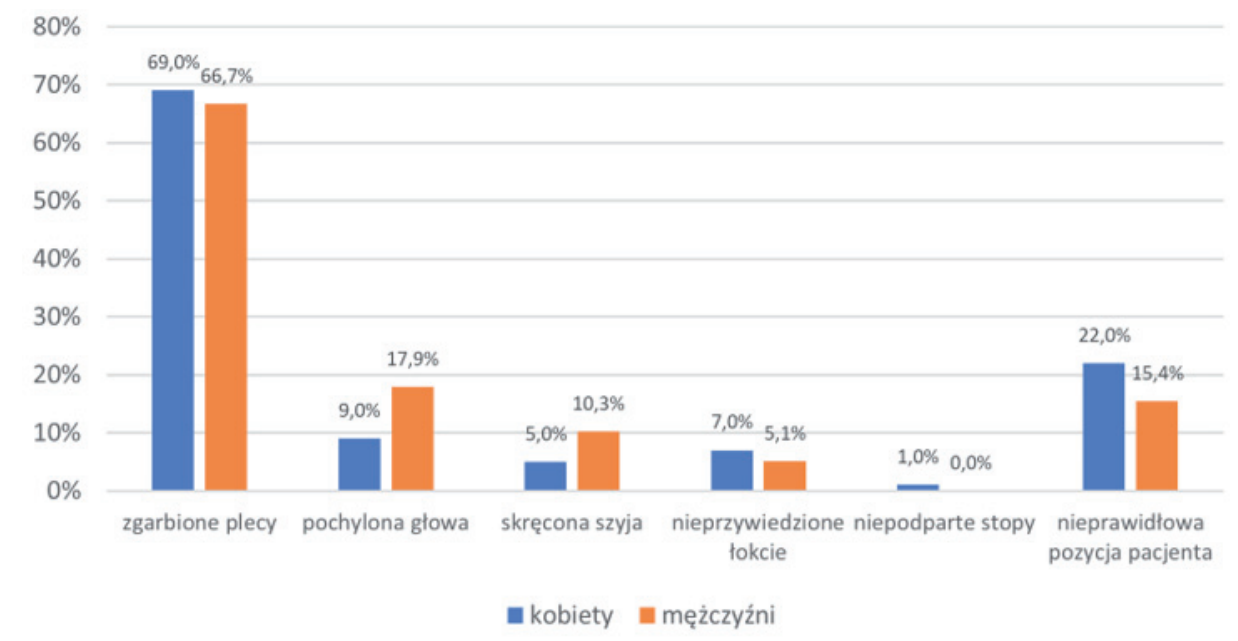

Rycina 3. Na jakie błędy asystent zwracał Ci uwagę?

Figure 3. What mistakes did the assistant point out to you?

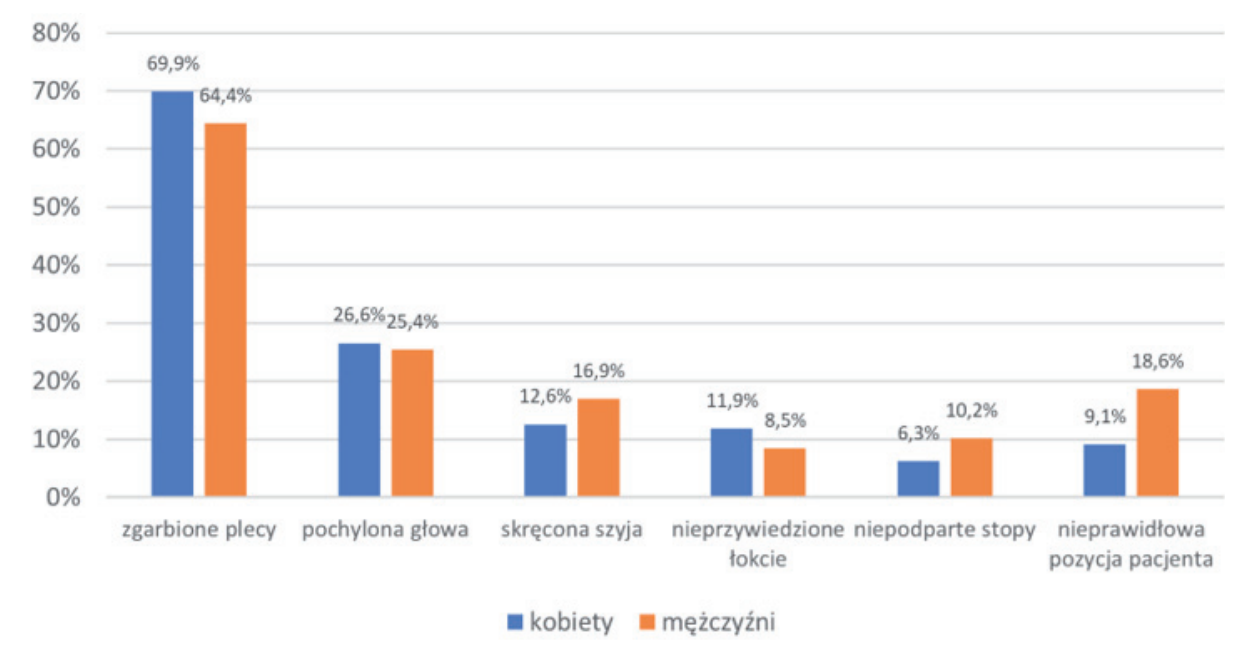

Rycina 4. Jakie błędy zauważasz u koleżanek/kolegów?

Figure 4. What mistakes do you notice in your colleagues? 


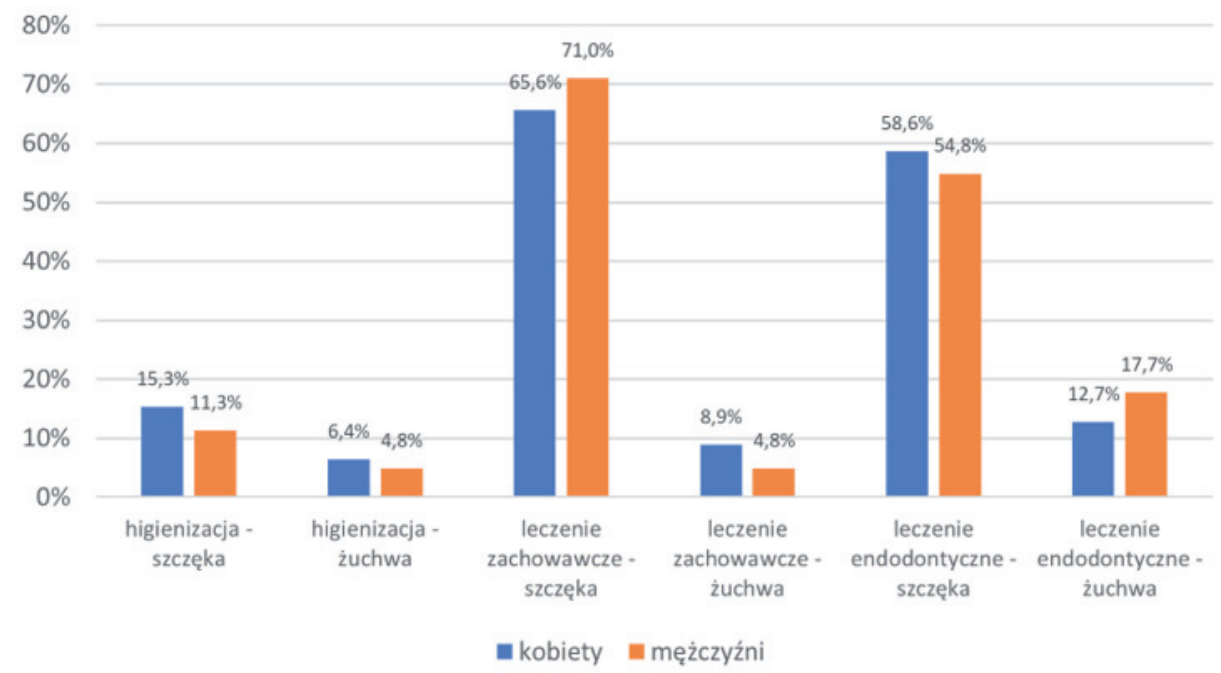

Rycina 5. Jakie błędy dostrzegałaś/eś u lekarzy na praktykach?

Figure 5. What mistakes have you noticed in doctors during summer internships?

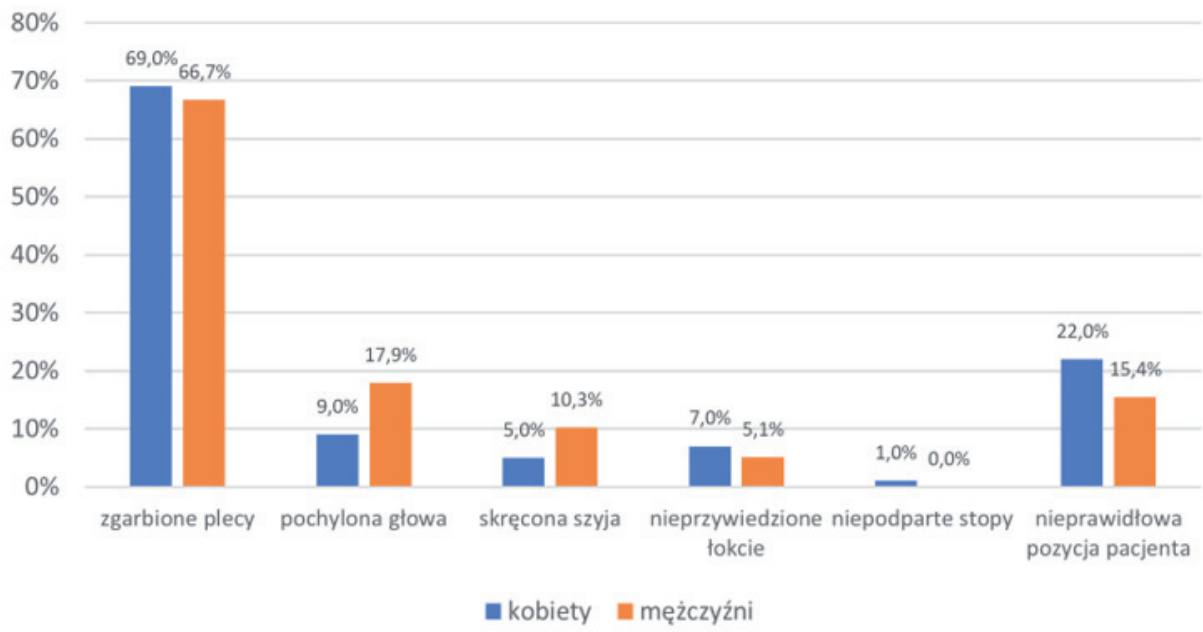

Rycina 6. Podczas pracy klinicznej dolegliwości dotyczą najczęściej...

Figure 6. In clinical work, the most common complaints are...

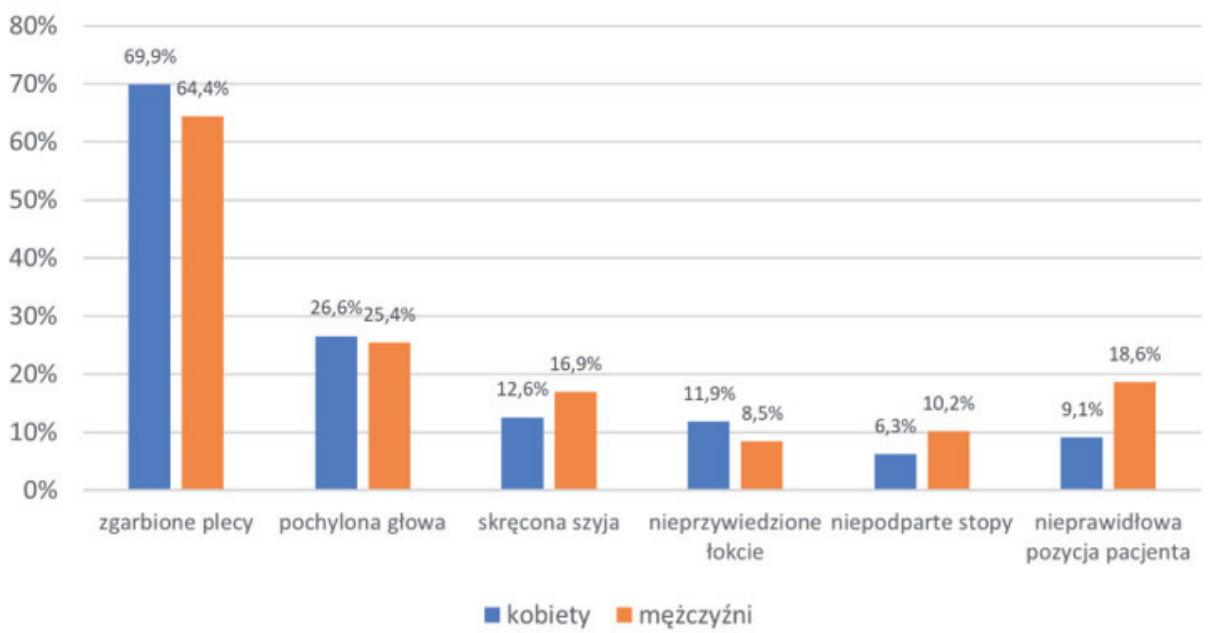

Rycina 7. Po pracy klinicznej dolegliwości dotyczą najczęściej...

Figure 7. After clinical work, the most common complaints are... 
chowaniu ergonomicznej pozycji podczas wykonywania zabiegów leczniczych, szczególnie w obrębie zębów szczęki. Studenci nie przestrzegają zasad ergonomii pracy, pochylając się lub wykonując skręty boczne szyi, zazwyczaj właśnie z powodu utraty dobrej widoczności pola zabiegowego. Z kolei wśród preferowanych aktywności sportowych do najpopularniejszych, niezależnie od płci, należały: siłownia, fitness, bieganie czy też jazda na rowerze. Ankietowani wykonywali te czynności z reguły kilka razy w tygodniu, natomiast mediana czasu poświęcanego na aktywność fizyczną w ciągu tygodnia wynosiła dla kobiet 3 godziny, a dla mężczyzn 4 godziny.

\section{Dyskusja}

Badanie wykazało, iż ponad 90\% studentów zna zasady pracy ergonomicznej. Jednak niestety odsetek badanych, którzy wdrażają w życie poszczególne zasady ergonomii pracy jest już znacznie niższy. Koronny przykład stanowi utrzymywanie podczas zabiegu prostych pleców. Chociaż 72,6\% kobiet i 69,4\% mężczyzn zadeklarowało wyprostowane plecy w trakcie pracy, to pytania otwarte dowiodły, iż właśnie z zachowaniem tej zasady ma problem większość badanych. Aż 94,3\% kobiet i 82,3\% mężczyzn wykorzystuje boczne zgięcie tułowia i szyi w celu poprawy pola widzenia. W pytaniach otwartych ankietowani tłumaczyli, iż wolą obserwować pole operacyjne bezpośrednio, a nie przy pomocy lusterka, między innymi ze względu na problemy z koordynacją ruchów czy też odpowiednim ustawieniem oświetlenia. Wydaje się to dużym problemem, gdyż większość badanych za najtrudniejsze do leczenia uważa zęby szczęki. Być może poprawa jakości lusterek diagnostycznych, odpowiedni ich dobór (przedniopowierzchniowe, szczególnie do leczenia endodontycznego) pozwoliłaby na bardziej ergonomiczną postawę przy pracy. Ponad połowa studentów doświadczyła także uwag ze strony asystenta. Najczęściej zwracali oni uwagę na zgarbione plecy i błędną pozycję fotela. Ankietowani dostrzegają także nieprawidłową pozycję wśród swoich kolegów oraz starszych lekarzy, co niewątpliwie świadczy o znajomości teorii ergonomii. U starszych lekarzy stomatologów obserwowali często pracę w pozycji stojącej przy siedzącym pacjencie.

Konieczne wydaje się znalezienie odpowiedzi na pytanie, co zrobić, aby studenci stomatologii jako przyszli lekarze dentyści mogli pracować jak najdłużej w najlepszym zdrowiu. Wśród badaczy nie ma jednomyślności w tej kwestii. Część z nich sugeruje, że odpowiedni trening podczas studiów wystarczy, aby zlikwidować trudności związane z wykonywaną procedurą i utrzymaniem pozycji ergonomicznej [9, 15]. Z kolei Bagińska i wsp. [16] stwierdzili, iż w toku studiów nie następowała poprawa umiejętności zachowania prawidłowej postawy przy pacjencie. Autorzy wskazują również możliwość stosowania powiększenia pola operacyjnego. Wykazano, że lupy pozytywnie wpływają na postawę pracującego studenta, ale niestety nie na jakość preparacji [17].

Co interesujące, niemal 100\% ankietowanych kobiet i mężczyzn przyznało, iż są świadomi tego, że regularna aktywność fizyczna pomaga w utrzymaniu odpowiedniego napięcia mięśniowego. Niestety - pomimo tej wiedzy - sport uprawia tylko 65\% kobiet. Odsetek ćwiczących mężczyzn jest znacznie wyższy i wynosi $87,1 \%$.

Świetnym programem do szybkiej analizy pozycji przy pracy jest metoda REBA (ang. Rapid Entire Body Assessment) określająca wielkość ryzyka wystąpienia dolegliwości ze strony układu mięśniowo-szkieletowego [13, 18]. Być może szersze zapoznanie nauczycieli akademickich z tym programem pozwoliłoby na skuteczniejszą interwencję w sytuacjach zagrożenia zdrowia. Nie ulega wątpliwości, iż należy poprawić pozycję studentów stomatologii w pracy. Oprócz szeroko zakrojonej i spójnej edukacji należy wziąć pod uwagę działania profilaktyczne, takie jak np. projekt stanowiska pracy, zaplanowane okresy odpoczynku podczas pracy czy też regularne ćwiczenia fizyczne.

\section{Podsumowanie}

Praca zgodna z zasadami ergonomii może stanowić duże wyzwanie dla każdego lekarza dentysty. Niezmiernie ważne wydaje się ukształtowanie właściwych nawyków już na etapie edukacji przeddyplomowej. Warto zwrócić uwagę na fakt, iż znajomość teoretycznych zasad pracy ergonomicznej nie gwarantuje właściwej pozycji podczas pracy z pacjentem. Dużą rolę w wyćwiczeniu automatyzmu ergonomicznego może odegrać nauczyciel akademicki, obserwujący studenta i udzielający odpowiednich wskazówek podczas pracy klinicznej. Praktykowanie stomatologii bez dolegliwości związanych z układem mięśniowo-szkieletowym zapewnia lepszą jakość wykonywanych zabiegów, dłuższą karierę zawodową i większe zadowolenie z pracy, a w konsekwencji lepszą jakość życia.

\section{Oświadczenia}

\section{Oświadczenie dotyczące konfliktu interesów}

Autorzy deklarują brak konfliktu interesów w autorstwie oraz publikacji pracy. 


\section{Źródła finansowania}

Autorzy deklarują brak źródeł finansowania.

\section{Piśmiennictwo}

[1] Kapitán M, Pilbauerová N, Vavřičková L, Šustová Z, Machač S. Prevalence of musculoskeletal disorders symptoms among czech dental students. part 1: a questionnaire survey. Acta Medica (Hradec Kralove). 2018;61(4):131-6.

[2] Ohlendorf D, Erbe C, Hauck I, Nowak J, Hermanns I, Ditchen D, et al. Kinematic analysis of work-related musculoskeletal loading of trunk among dentists in Germany. BMC Musculoskelet Disord. 2016;17(1):427.

[3] Fernandez de Grado G, Denni J, Musset A-M, Offner D. Back pain prevalence, intensity and associated factors in French dentists: a national study among 1004 professionals. Eur Spine J Off Publ Eur Spine Soc Eur Spinal Deform Soc Eur Sect Cerv Spine Res Soc. 2019;28:2510-16.

[4] Meisha DE, Alsharqawi NS, Samarah AA, Al-Ghamdi MY. Prevalence of work-related musculoskeletal disorders and ergonomic practice among dentists in Jeddah, Saudi Arabia. Clin Cosmet Investig Dent. 2019;11:171-9.

[5] de Jesus Júnior LC, Tedesco TK, Macedo MC, Agra CM, Mello-Moura AC, Morimoto S. A self-report joint damage and musculoskeletal disorders data among dentists: a cross-sectional study. Minerva Stomatol. 2018;67(2):62-7.

[6] Radanović B, Vučinić P, Janković T, Mahmutović E, Penjašković D. Musculoskeletal symptoms of the neck and shoulder among dental practitioners. J Back Musculoskelet Rehabil. 2017;30(4):675-9.

[7] Botta AC, Presoto CD, Wajngarten D, Campos J a. DB, Garcia PPNS. Perception of dental students on risk factors of musculoskeletal disorders. Eur J Dent Educ Off J Assoc Dent Educ Eur. 2018;22(4):209-14.

[8] Jahanimoghadam F, Horri A, Hasheminejad N, Hashemi Nejad N, Baneshi MR. Ergonomic evaluation of dental professionals as determined by Rapid Entire Body Assessment method in 2014. J Dent Shiraz Iran. 2018;19(2):155-8.

[9] Shirzaei M, Mirzaei R, Khaje-Alizade A, Mohammadi M. Evaluation of ergonomic factors and postures that cause muscle pains in dentistry students' bodies. J Clin Exp Dent. 2015;7(3):e414-8.

[10] Rafeemanesh E, Jafari Z, Kashani FO, Rahimpour F. A study on job postures and musculoskeletal ilInesses in dentists. Int J Occup Med Environ Health. 2013;26(4):615-20.
[11] Movahhed T, Dehghani M, Arghami S, Arghami A. Do dental students have a neutral working posture? J Back Musculoskelet Rehabil. 2016;29(4):859-64.

[12] Nowotny-Czupryna O, Czupryna K, Skucha-Nowak M, Szymańska J. Spine arrangement during work in sitting position and occurrence of pain among dentists and medical assistants. Med Pr. 2018;69(5): 509-22.

[13] Aghahi RH, Darabi R, Hashemipour MA. Neck, back, and shoulder pains and ergonomic factors among dental students. J Educ Health Promot. 2018;7:40.

[14] Samoladas E, Barmpagianni C, Papadopoulos DV, Gelalis ID. Lower back and neck pain among dentistry students: a cross-sectional study in dentistry students in Northern Greece. Eur J Orthop Surg Traumatol Orthop Traumatol. 2018;28(7):1261-7.

[15] Neves T da C, Viana LN, Wajngarten D, Garcia PPNS. Preclinical dental training: Association between difficulty in performing restorative procedures and the adoption of ergonomic posture. Eur J Dent Educ Off J Assoc Dent Educ Eur. 2019;23(3):373-7.

[16] Bagińska J, Tworkowski K, Masłowska A, Kobus A, Kierklo A. Whether dental students follow ergonomic rules when working with patients - a pilot study, Hygeia Public Health 2018;53(3):283-287.

[17] Carpentier M, Aubeux D, Armengol V, Pérez F, Pru$d$ 'homme T, Gaudin A. The effect of magnification loupes on spontaneous posture change of dental students during preclinical restorative training. J Dent Educ. 2019;83(4):407-15.

[18] Kim J, Park B-Y, Mun S-J, Shim J, Choi E-S, Noh H. Differences in plantar pressure by REBA scores in dental hygienists. Int J Dent Hyg. 2019;17(2):177-82.

Zaakceptowano do edycji: 2020-10-06 Zaakceptowano do publikacji: 2020-10-06

\author{
Adres do korespondencji: \\ Kacper Nijakowski \\ Klinika Stomatologii Zachowawczej i Endodoncji, \\ Uniwersytet Medyczny im. Karola Marcinkowskiego \\ w Poznaniu \\ ul. Bukowska 70 \\ 60-812 Poznań \\ e-mail: kacpernijakowski@ump.edu.pl
}

